\title{
Summer Records of the Sandhill Crane in Saskatchewan
}

\author{
by Lawrence H. Walkinshaw, Battle Creek, Michigan
}

There are a number of Sandhill Crane records from Saskatchewan during the summer months. There are few recent nest records. The breeding subspecies is the Greater Sandhill Crane (Grus canadensis tabida) but the size of some eggs collected and of one female taken at a nest indicate it is possible that the Lesser Sandhill Crane (G.c. canadensis) may nest farther south than supposed. A few summer specimens could help solve this prcib'em but the species has been too rare as a breeder to be collected in any numbers. The following reccrds are those we have obtained for summer birds or nests from Saskatchewan:

R. P. Allen and R. Smith in their search for the Whooping Crane (Grus americana) found Sandhill Cranes in 1947 as follows:

(1) Churchill Lake (T83, at about the inter'section of R16 and R17). June 14, three cranes observed.

(2) Lac Ile a la Crosse, west side (T76,R13). June 10, two cranes.

(3) Niska Lake, mouth of McCusker River (T76,R18). June 10, two cranes.

(4) Ile a la Crosse Village, NW of Lac La Plonge (T74, Ri1). June 9 , two cranes.

(5) Primrose Lake, 5 miles east (T68,R23). June 8, one crane.

(6) Aubichon Lake (T65,R13). June 9, a pair chased their plane and ran around beneath them with drooping wings. are:

Other Saskatchewan observations

(7) Lac Ile a la Crosse, just east of north end. Angus Buchanan (1920) found a nest with 2 eggs along the marshy shore of a nearby lake, May 30, 1914.

(8) Montreal Lake, north of north end (T63-64, R24-25W2). F. Mowat (1946) found breeding Sandhill Cranes in May, 1946.

(9) Dorintosh (T62,R18W3). C. F. Shirley (Godfrey, 1950) said cranes still summer here; no positive breeding evidence.

(10) Cariton to Cumberland (along Saskatchewan River). Summer; common, Richardson (Houston and Street, 1959).

(11) Emma Lake (T53R1W3). Observed at summer meeting S.N.H.S., June 13-15, 1958 (Blue Jay, 1958, 16:141).

(12) Snowden (T53,R19W2, Sect.10). just east of Jacquine Lake. I found two Sandhill Cranes here June 14, 1947. The birds ran around me as if with broken wings but I could not find the young which must have hidden in the tall grasses and sedges. The next day they were not there. On June 14, I also observed two cranes in T53,R18, Sect. 6 and heard two calling in Sect.2,R19, on June 16.

(13) Campbell Lake (T51,R16W2). M. Street (1946) observed adults with young in August, 1943. F. Bard (letter, 1947) observed two cranes on two occasions in late June, 1945. M. Street, D. A. Munro, W. A. Tholen and I observed a lone crane and heard another June 5, 1947. Sandhill Cranes apparently nest here most years. (Houston and Street, 1959).

(14) Niska Lake (T51,R1W2). F. Bard observed two pairs June 10 and one pair June 11, 1939. The pair on June 11 remained close all day as though they had young nearby.

(15) Mountain Cabin at Carrot River (T53,R1W2). F. Bard (letter, 1947) heard cranes calling May 26 and May 30, 1939.

(16) Cochin, 24 miles NW, La Motts Muskeg (T48,R16W3). F. Bard (letter, 1947), observed two cranes May 21, 1935. One bird did not move for over an hour. When flushed they flew only a short distance then returned to the same area. Another crane was seen June 10, 1935. 
(17) Waterhen Marsh, near Kinistino (T45,R21W2). R. T. Congdon observed cranes here during the 1902 summer; there were none here in 1955 (S. and M. Houston, 1955).

(18) Carlton, Saskatchewan Plains (T43-44,R4W3). Specimen taken May 3, 1858, and an egg collected by Thos. Blackiston (1862). Concerning the specimen taken he wrote (1863), measured; wings 19 to 21 in.; bill, along ridge, 5 in. (definitely G.c. tabida). One observed near in a large marsh July 27, 1939, by Mowat (Houston and Street, loc.cit.).

(19) Big Quill Lake (T33-34,R1718W2). J. F. Ferry (1910), giving Barnes as the finder, listed a nest found June 20, 1909, with one broken egg. There is a male specimen (Royal Ont.Mus.Zool.) taken June 25, 1915, and another male taken south of here June 8, 1884.

(20) Dafoe (T32,R18W2). H. H. Mitchell (notes from Sask.Prov. Mus.), observed one pair June 21,1915 ; another pair June 23, 1915 , and a male and female and one young June 24, 1915.

(21) Kutawagan Lake (T30,R24W2). H. H. Mitchell (Sask.Prov.Mus. Notes), observed cranes June 7 , June 14 , June 16 , June 18 , and June 20, 1917. P. A. Taverner (letter, 1942), found downy chick June 5, 1920 (Nat.Mus. Canada) and there are two specimens in the National Museum of Canada taken here: male (15438) June 5, 1920, and female (15544) June 14, 1920.

(22) Last Mountain Lake area (T28N). There are many records listed by Fred Bard (Sask. Prov.Mus. notes) from the area of Last Mt. Lake: Govan, Valeport, Young, Craven, Imperial Beach, Keddleston, and Condie, where cranes are regularly observed during spring and fall. At Stalwart Marsh, R. Smith (verbal, 1947) observed a pair of cranes about May 25, 1947. W. Tholen and I observed a flock of 41 on May 27, 1947, just north of Last Mt. I ake (migrants?).
(23) Good Spirit Lake (T29,R5W2). J. Gunn (Houston, 1949) reported Sandhill Cranes plentiful all summer for about eight years after 1888 and found a nest about two miles south of the lake, about 1890 .

(24) Willowbrook (T25,R6W2). R. P. Rooke (Hcuston, 1949), in a place called "The Ravine," about one mile west and three miles south of where the village of Willowbrook is today, found in June, 1893, 10 nests each with two eggs.

(25) Rousay Lakes (T25,R4W2). R. Rousay (Houston, 1949) reported cranes were regular and common breeders in the 1890's.

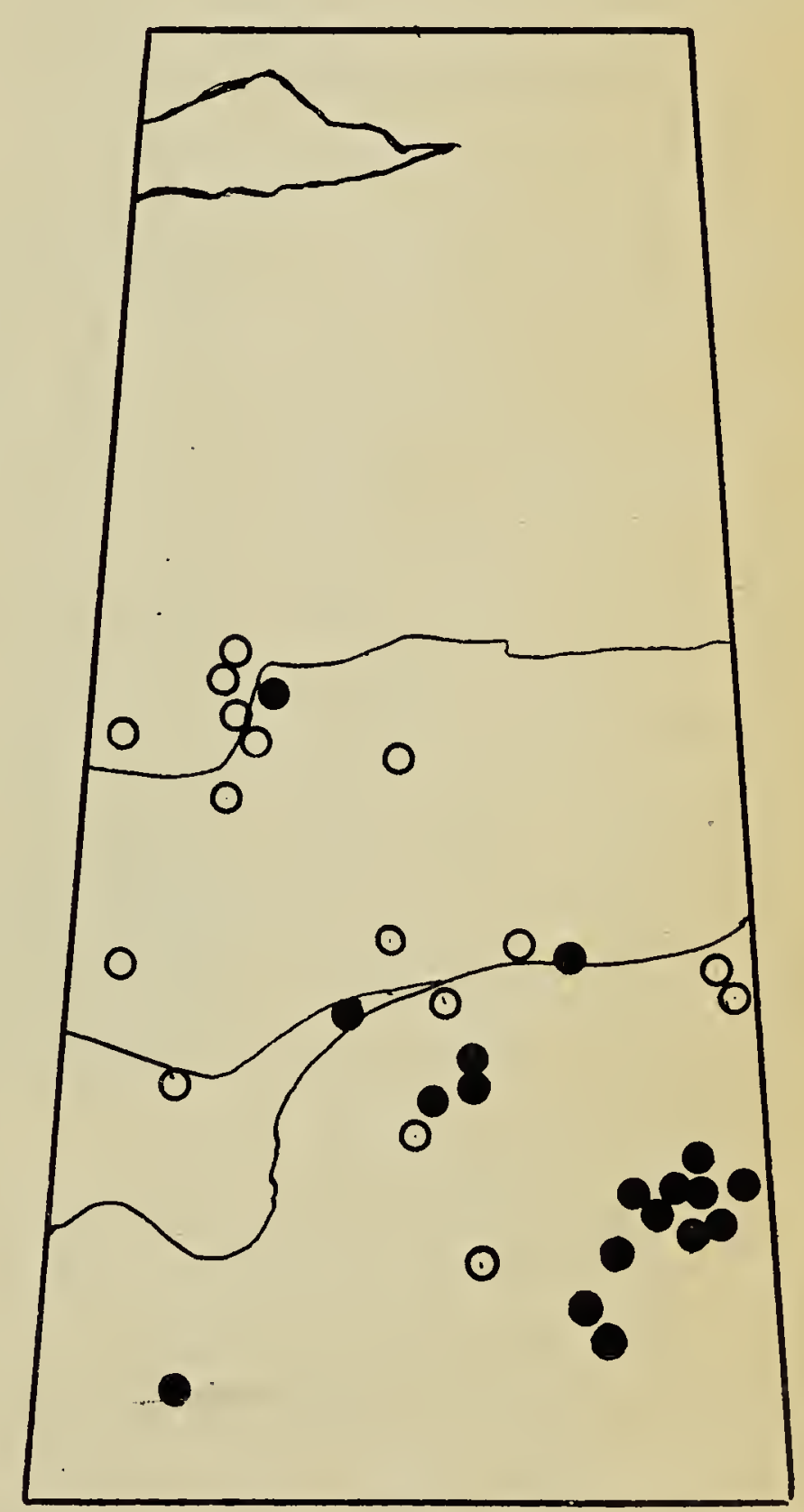

THE SANDHILL CRANE IN SASKATCHEWAN IN SUMMER

O-Sight Records

- -Breeding Records 
(26) Crescent Marsh (T23,R3W2). Frank Baines' father shot two birds here in 1884 (Houston, 1949 ) definitely, from measurements, G.c. tabida. One spring day in the 1890's Fred Baines found three cranes' nests, each with two eggs, in Section 20 and several other nests including a set of two eggs, May 27, 1899 (Mus.Comp.Zool.). He also raised two cranes, brother and sister, which nested their third summer and hatched a litille one which died when nine days old. Not common here now (Baines, 1956). C. H. Maddaford (Houston, letter) found a nest with one egg either 1910 or 1911 .

(27) Rokeby Marsh (T23-24,R3W2). Mr. McInnes (Houston, 1949) found five nests between 1938 and 1940. F. G. Bard also observed a pair of cranes here, apparently nesting, in June, 1941. A nest with one egg was found May 5, 1954, by John Maddaford, who showed it to Dr. C. S. Houston (1955) May 10. The egg measured $93.5 \mathrm{x}$ $60.5 \mathrm{~mm}$. C. H. Maddaford found two nests with eggs in the Rokeby Marsh about 1918. The 1954 nest was in Sect.12,T24N.

(28) McNichol Slough (T23,R2W2, Sect.34). Frank Baines' son (Houston, 1949) found a nest with eggs which had been destroyed in 1942. His father had found nests here 50 years earlier. Near here Baines found a nest with eggs, July 1 , in the 1890's (one mile east and two miles south of Yorkton).

(29) Calder (T24,R31W1). E. C. Major (Houston, 1949) came upon an adult crane with two small young on high ground five miles south and three miles west of Calder, about June 20, 1945.
(30) Grayson (T20,R5W2). Allen Palmer (Fred Bard notes) coliected two eggs April 11, 1914 (Sask. Mus. Nat. Hist.). . These eggs were stolen from the lviuseum case.

(31) Baigonie (T18,17W2). Bent (1927) listed this as a breeding area but gave no data.

(32) Tyvan (T12,R13W2). Sandhill Cranes' nests were found here abcut 1914 as reported to Dr. C. J. Houston (Blue Jay, 1946: 44).

(33) Near Fillmore (T11,R11W2). Gerald Clay (verbal) found a nest with two eggs during the spring of 1918 and in the spring of 1919 caught a young bird which he tried to raise but it later died.

(34) Instow (T9,R17W3). A set of two eggs was taken here June 4, 1901 (Chicago Mus.Nat.Hist.).

Thus actual nest records are not very common from Saskatchewan during the past 20 years. I find only four areas where the species has been found nesting: Campbell Lake, Rokeby Marsh, McNichol Slough and at Calder. However, cranes have been observed regularly in several other areas and judging from the behaviour of the birds they must have nested in several others. Probably in the northern and north central parts of the Province the species is still fairly common during the summer in favorable areas.

I have found four unquestionable records of breeding specimens from Saskatchewan. These birds are much smaller than breeding cranes from farther east and south in Wisconsin and Michigan but agree with some from North Dakota, Wyoming, Idaho and a few from Oregon as well as those from Alberta and Manitoba. Following are the measurements in millimeters of these birds:

Measurements (in mm.) of Sask. Breeding Specimens

\begin{tabular}{l|l|l|l|l|l|l|l}
\hline Museum & Where Taken & Date & Sex & Ex. Cul. & Tarsus & $\begin{array}{c}\text { Bare } \\
\text { Tibia }\end{array}$ & Wing \\
\hline ROMZ & S. Big Quill L. & June 9,1884 & M & 121 & 239 & 96 & 488 \\
ROMZ & Big Quill L. & June 25,1915 & M & 127 & 236 & 96 & 495 \\
NMC & Kutawagan L. & June 5, 1920 & M & 124 & 236 & - & 523 \\
NiMC & Kutawagan L. & June 14, 1920 & F & 114 & 216 & - & 467 \\
\hline
\end{tabular}




\title{
REFERENCES CITED
}

BAINES, K. E. -1956 . The ups and downs of game at Crescent Lake. Blue Jay, 14:6566.

BENT, A. C.-1927. Life Histories of North American Marsh birds. U.S. Nat1. Mus. Bull. 135.

BLAKISTON, T. -1862. On birds collected and observed in the interior of British North America. Pt. 2. Ibis, 4 (ser. 1) : 3-10.

1863. On the birds of the interior of British North America (Pt. 2 ). Ibis, 5 (ser. 1): 121155.

BUCHANAN, A.-1920. Wildlife in Canada. McClelland, Goodchild and Stewart, Ltd., Toronto.

FERRY, J. F.-1910. Birds abserved in Saskatchewan during the summer of 1909. Auk, 27:185-204.

GODFREY, W. E.-1950. Birds of the
Cypress Hills and Flotten Lake Regions, Saskatchewan. Natl. Mus. of Canada, Bull. No. 120. HOUSTON, C. S.-1949. The birds of the Yorkton district, Saskatchewan. Canadian FieldNaturalist, 63:215-241.

1955. Sandhill Crane nesting at Rokeby Marsh. Blue Jay, 13:9.

HOUSTON, C. S. and M. HOUSTON1955. Following Congdon-53 years later. Blue Jay, 13:18-19.

HOUSTON, C. S. and M. G. STREET1959. The birds of the Saskatchewan River, Carlton to Cumberland. Spec. Publ. No. 2 Sask. Nat. Hist. Soc.

MOWAT, F.-1946. Bird watching from a "Jeep." Blue Jay, 4:39.

STREET, M. G.-1946. A list of the birds of Nipawin, Saskatchewan, mimeographed July, 1943 (Cont. \#2-Y.N.H.S.) Blue Jay, $4: 45$.

\section{The Use of Exploders in Protecting Crops Against Sandhill Crane Depredation}

\author{
By W. J. D. Stephen, Canadian Wildlife Service, Saskatoon
}

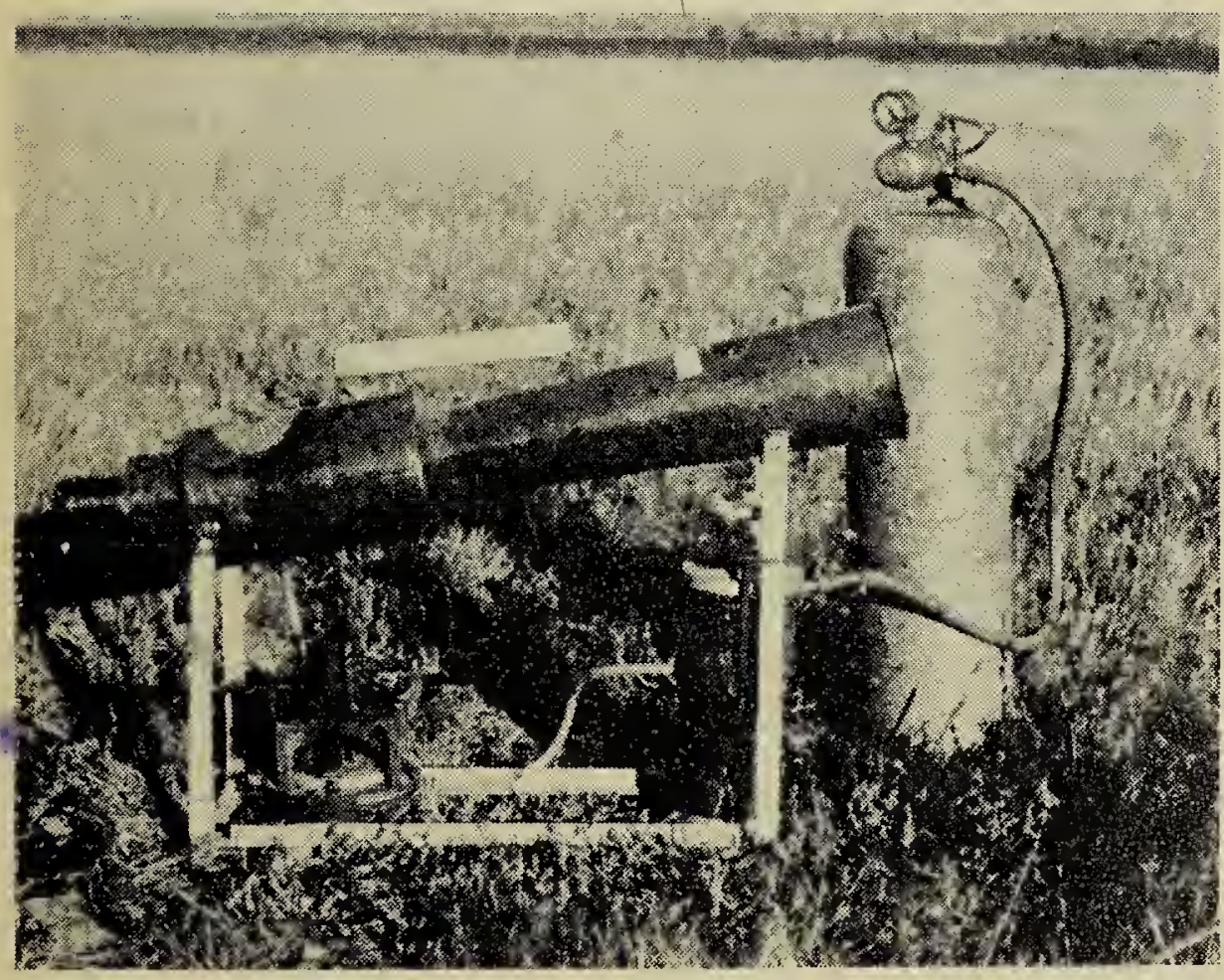

Zon Acetylene Exploder

Oct. 5, 1959, Thackeray Lake, Sask. protection, but we do very little toward finding a solution to the problem of crop depredation $w \mathrm{~h}$ i $\mathrm{c} \mathrm{h}$ would help to reinstate the bird in the farmer's eyes. Many of the farmers of this country are naturalists themselves, whether they know it or not. They, too, would come to think of the Sandhill Crane as a valuable part of our wildlife legacy, if they could be protected from the damage it does to their crops.

There are several ways of giving Sandhill Cranes some positive value in the eyes

In an article on Sandhill Cranes in the last issue of the Blue Jay (XVII: $141-2)$, T. A. Harper posed the provocative question: "How much are Sandhill Cranes worth to you?" To this question the agriculturist would give a negative answer because he is naturally inclined to regard the Sandhill Crane as a destructive bird, of nuisance value only. Some of the rest of us, who call ourselves naturalists, do realize the positive vallie of the Sandhill Crane and ask for its of the agriculturist. For example, we might encourage people to look on them as valuable game birds by opening a hunting season and making it necessary to have a licence to kill them!

More conservatively, there are other practical measures that are worth investigating. Exploders and other such devices have been used to prevent duck depredations. Last Octaber one of these exploders was used to prevent cranes from landing 